\title{
KEWENANGAN PEMBE RIAN IZIN PERUBAHAN PENGGUNAAN TANAH (IPPT) DI KABUPATEN KARANGANYAR
}

\author{
Agus Riyanto \\ Mahasiswa Program Magister Hukum Fakultas Hukum UNS \\ e - mail : agusriyanto_jogja@yahoo.com \\ I Gusti Ayu Ketut Rachmi Handayani \\ Dosen Fakultas Hukum Universitas Sebelas Maret Surakarta \\ e - mail : ayu_igk@yahoo.com
}

\begin{abstract}
The objectives of this article are : (1) to investigate the implementation of licensing authority on the land use change from agricultural land to the non- agricultural one in Karanganyar Regency, of Central J ava Province from 2013 - 2015 and (2) to investigate and analyze the reasons behind the inabilities of the local government of Karanganyar Regencyin the implementation of its licensing authority on land use change.This research used the non-doctrinal evaluative research method, i.e. the empirical studies to find theories on the rule of laws and the working of laws in community by reffering to the theory of law effectiveness claimed by Soerjono Soekanto. The result of research shows that the implementation of licensing authority on land use change from the agricultural land to the non-agricultural until 2015 was still done by the Land Office of Karanganyar Regency because the government of Karanganyar did not have legal instruments, technical infrastructures and facilities, and human resources required to support the implementation of the aforementioned authority.
\end{abstract}

Keyword : Authority, Licencing, Land Use Change Permit, Agricultural Land, non- Agricultural land.

\begin{abstract}
Abstrak
Tujuan dari artikelini adalah untuk mengetahui pelaksanaan kewenangan pemberian izin perubahan penggunaan tanah pertanian ke non pertanian di Kabupaten Karanganyar, Propinsi J awa Tengah Tahun 2013 - 2015 dan untuk mengetahui serta menganalisis alasan-alasan yang menjadi penyebab Pemerintah Daerah Kabupaten Karanganyar belum mampu melaksanakan kewenangannyasendiri dalam pemberian Izin Perubahan Penggunaan Tanah (IPPT) tersebut. J enis Penelitiannya adalah Non Doktrinal,yaitu penelitian berupa studi-studi empiris untuk menemukan teori-teori mengenai proses terjadinya dan mengenai proses bekerjanya suatu hukum di dalam masyarakat, dengan mengacu teori efektifitas hukum yang dikemukakan oleh Soerjono Soekanto, sedangkan bentuk penelitiannya adalah penelitian evaluatif. Dari hasil penelitian menunjukan bahwa pelaksanaan kewenangan pemberian Izin Perubahan Penggunaan Tanah (IPPT) dari Tanah Pertanian menjadi Tanah Non Pertanian sampai Akhir Tahun 2015 masih dilaksanakan oleh Kantor Pertanahan Kabupaten Karanganyar. Hal ini disebabkan karena Pemerintah Kabupaten Karanganyar belum mempunyai perangkat/instrumen hukum, sarana/ prasarana teknis serta SDM (Sumber Daya Manusia) yang diperlukankan dalam mendukung pelaksanaan kewenangan dimaksud.
\end{abstract}

Kata Kunci : Kewenangan, Perizinan, Izin Perubahan Penggunaan Tanah, Tanah Pertanian, Tanah Non Pertanian.

\section{A. Pendahuluan}

Seiring dengan pertumbuhan jumlah penduduk yang semakin banyak dan perkembangan pembangunanekonomi yang semakin pesat, menuntutketersediaan tanah yang relatif mencukupi. Di lain pihak, ketersediaan tanah khususnya tanah pertanian (sawah/ tegalan), justru semakin hari semakin menyusut, sebagai akibat maraknya konversi/alih fungsi/ perubahan penggunaan tanah untuk kegiatan non pertanian, seperti keperluan industri, perumahan, perkantoran, investasi, dan keperluan tempat tinggal. Hal ini menimbulkan kekhawatiran yang sangat serius bagi pemerintah, pihak-pihak yang bertanggung jawab di bidang pertanian dan ketahanan pangan maupun para pakar di Perguruan Tinggi, karena jika alih fungi/konversi 
dari dari tanah-tanah pertanian ke non pertabnian ters ebut tidak dikendalikan, maka lama-kelamaan ketersediaan tanah pertanian akan habis.

Berdasarkan Data Biro Pusat S tatistik (BPS) bahwa luas lahan sawah Indonesia pada Tahun 1993 seluas \pm 8.500 .000 (delapan juta lima ratus ribu) Hektar, kemudian pada Tahun 2000 telah terjadi penyusutan serius menjadi seluas \pm 7.700 .000 (tujuh juta tujuh ratus ribu) Hektar atau susutnya mencapai \pm 710.000 (tujuh ratus sepuluh ribu) Hektar, atau setiap tahunnya tanah sawah di Indonesia menyusut seluas $\pm 101.428,6$ (seratus satu ribu empat ratus dua puluh delapan koma enam) Hektar (BPS, 2001).

Penyusutan luas tanah pertanian (sawah) tersebut di atas, sebagian besar disebabkan oleh adanya alih fungsi/konversi atau perubahan penggunaan tanah untuk keperluan non pertanian. Sebagai contoh atau ilustrasi atas tanah-tanah pertanian yang dikonversi menjadi non pertanian selama tahun 2000-2002, yang dipergunakan untuk pembangunan nonpertanian, seperti kawasan perumahan, industri, perkantoran, jalan, dan sarana publik lainnya rata-rata sebesar 110.160 (seratus sepuluh ribu seratus enam puluh) hektar per tahun (Data dari Balai P enelitian Agroklimat dan Hidrologi DAS Krueng - Bogor, 2011). Kemudian pada Tahun 2008, luas tanah pertanian yang tersisa di Indonesia adalah sebesar \pm 7.700 .000 (tujuh juta tujuh ratus ribu) hektar, dengan laju konversi sebesar 110.000 (seratus sepuluh ribu) hektar per tahun (Hasil Temuan Pusat Analisis Sosial Ekonomi dan Kebijakan Pertanian Bersama StaF Direktorat Pangan dan Pertanian, Kantor meneg PPN/BAPPENAS, 2008).

Adapun faktor-faktor yang menjadi penyebab adanya alih fungsi menurut Nasoetion dan Rustiadi, yaitu besarnya tingkat urbanisasi akibat lambannya proses pembangunan di wilayah pedesaan, meningkatnya jumlah anggota kelompok golongan yang pendapatan menengah dan atas di wilayah perkotaan yang mengakibatkan bertambah besanya permintaan sarana pemukiman, serta terjadinya transformasi di dalam struktur perekonomiam Indonesia, yang dicirikan oleh cepatnya pertumbuhan sector industri, yang pada gilirannya akan mendesak kegiatan pertanian dan lahan sawah (Nasoetion dan Rustiadi, 1990 : 3-4).

Sedangkan menurut Maria Sumardjono, perubahan penggunaan tanah pertanian itu tidak terbatas untuk perumahan saja tetapi untuk kegiatan lain di luar pertanian. Pemekaran daerah industri, penambahan jaringan jalan dan berbagai prasarana lain sebagai tuntutan pembangunan ikut menentukan dalam pengurangan areal tanah pertanian. Bahkan, menurut Maria Sumardjono, sampai saat ini kelihatannya jumlah penduduk masih merupakan factor yang menonjol dalam perubahan penggunaan tanah (Maria Sumardjono, $2001: 7)$.

Menurut Mc Neil (1998) factor-faktor yang mendorong perubahan penggunaan lahan adalah :

"politik, ekonomi, demografi dan budaya. Aspek politik adalah adanya kebijakan yang dilakukan oleh pengambil keputusan mempengaruhi perubahan penggunaan lahan. Pertumbuhan ekonomi, perubahan pendapatan dan konsumsi juga merupakan factor penyebab perubahan penggunaan tanah (Linda DR , 2011 : 75).

Kemudian menurut Syarif Imam Hidayat, dalam kesimpulan penelitiannya terhadap konversi penggunaan lahan di J awa Timur Tahun 19972006 antara lain menyatakan bahwa...." 2. Factor yang mempengaruhi konversi (alih fungsi) lahan sawah adalah variable jumlah rumah tangga, pertumbuhan ekonomi, dan jumlah petani (Syarif Imam Hidayat, 2008 : 56).

Govindaprasad.P.K and K. Manikandan dalam "Agricultural Land Conversion And food Security : A Thematic Analisys, "menyatakan yang dapat diterjemahkan sebagai berikut "Penganalisaan literature tersebut, menunjukkan bahwa penyebab utama dari konversi tanah pertanian adalah pertumbuhan jumlah penduduk, pertumbuhan ekonomi, dan perluasan perkotaan termasuk perumahan dan pengembangan infrastruktur dan akhirnya kegiatan spekulasi di lahan pertanian dari sisi permintaan konversi lahan pertanian (Govindaprasad.P.K and K. Manikandan, 2014 :14).

Dari pendapat Pakar/Ahli maupun Peneliti tersebut di atas, dapat disimpulkan bahwa faktor faktor penyebab terjadinya perubahan penggunaan lahan adalah :

a. besarnya tingkat urbanisasi :

b. pertumbuhan jumlah penduduk:

c. pertumbuhan ekonomi :

d. perluasan perkotaan termasuk perumahan dan pengembangan infrastruktur;

e. kegiatan spekulasi di lahan pertanian dari sisi permintaan konversi lahan pertania. 
Dengan demikian terjadi ketidakseimbangan yang begitu besar antara keterbatasan kesediaan atas tanahdi Indonesia dengan tuntutan kebutuhan tanah untuk keperluan proyek-proyek pembangunan, yang konversinya melalui sarana ijin lokasi/ penetapan lokasi.P ada awalnya tanahtanah pertanian yang mengalami alih fungsi atau perubahan pennggunaa adalah lahan-lahan pertanian yang kurang/tidak subur. Setelah persediaan lahan-lahan yang subur berkurang, maka baru mengarah ke tanah-tanah pertanian yang subur.

Kepala BPN Lutfi Nasoetion, dalam Harian Kompas edisi 13 J uni 2003 menyatakan pentingnya melestarikan lahan pertanian tidak hanya untuk kepentingan ketahanan pangan saja, tetapi juga untuk kelestarian lingkungan. Untuk itu, maraknya alih fungsi atau perubahan penggunaan tanah atas lahan-lahan pertanian yang subur harus dikendalikan oleh pemerintah, dengan mengeluarkan berbagai kebijakan di bidang perizinan yang sangat ketat), khususnya yang terkait dengan Izin Perubahan Penggunaan Tanah (IPPT) dengan luasan dibawah 1 (satu) hektar yang kewenangan pemberiannya ada pada Bupati/Walikota ( Lutfi Nasoetion : 2003).

Perencanaan adanya tanah-tanah yang dapat dialihfungsikan/dirubah penggunaan tanahnya oleh Pemerintah Daerah, sejatinya telah dipersiapkan dan dituangkan dalam Rencana Tata Ruang Wilayah Kabupaten/ Kota(RTRWK) yang berlaku, sehingga pada saat tanah-tanah tersebut akan digunakan untuk keperluan pembangunan oleh pemerintah daerah ataupun swasta, pemerintah tinggal mengeluarkan izin lokasi/penetapan lokasi dan izin perubahan penggunaan tanah pada tanah-tanah yang sudah ditunjuk dalam rencana tata ruang dimaksud.

Dalam Peraturan Daerah Kabupaten Karanganyar No. 1 Tahun 2013 Tentang Rencana Tata Ruang Wilayah Kabupaten Karanganyar Tahun 2013 - Tahun 2033 yang menjadi dasar atau pedoman untuk penerbitan perizinan, dinyatakan bahwa semua produk perizinan harus berpedoman kepada Rencana Tata Ruang Wilayah (RTRW) Kabupaten/Kota. Apabila terdapat izin pemnfaatan ruang (Izin lokasi/penetapan lokasi, rekomendasi pemanfaatan tanah, izin perubahan penggunaaa tanah dan perizinan lainnya) yang tidak sesuai dengan Rencana tata ruang Kabupaten/Kota, maka izin tersebut dibatalkan oleh Pemerintah dan Pemerintah Daerah menurut kewenangannya masing-masing.
Dalam pola ruang sebagaimana diatur dalam Peraturan Daerah No. 1 Tahun 2013 tersebut di atas, telah ditrisbusikan mengenai peruntukan ruang dalam suatu wilayah yang meliputi peruntukan ruang untuk fungsi lindung dan peruntukan ruang untuk fungsi budi daya. P roses penerbitan perizinan, baik untuk izin lokasi, penetapan lokasi dan izin perubahan penggunaan tanah harus mengacu/berpedoman pada pola ruang yang telah ditetapkan dalam Rencana Tata Ruang Wilayah Kabupaten, yakni tidak boleh berada pada kawasan lindung, seperti kawasan hutan, kawasan lahan pertanian basah, kawasan lahan pertanian kering, kawasan cagar budaya, dan kawasan perlindungan setempat.

Izin perubahan penggunaan tanah menjadi non pertanian (pekarangan) untuk tempat tinggal, baru dapat diberikan atau diterbitkan apabila tanah yang dimohonkan izin tersebut, terletak pada kawasan pemukiman perkotaan maupun pemukiman perdesaan atau kawasan industri. Izin perubahan penggunaan tanah tidak akan diterbitkan pada lahan-lahan yang peruntukannya selain untuk kawasan permukiman dan dihindari pada lahan-lahan pertanian yang subur atau produktif, karena mempengaruhi ketahanan pangan baik secara nasional maupun lokal. Oleh karena itu, agar lahan-lahan pertanian yang subur/produktif atau dikenal dengan nama Lahan Pertanian Pangan Berkelanjutan (LP2B) tersebut, terjaga keberadaannya dari alih fungsi menjadi non pertanian, maka Pemerntah menerbitkan berbagai surat edaran maupun peraturan perundangan guna melindungi lahan-lahan yang subur tersebut, yakni antara lain :

a. Undang-Undang No. 41 Tahun 2009 Tentang Perlindungan Lahan Pangan Berkelanjutan ( LP 2B);

b. Peraturan Pemerintah RI No. 1 Tahun 2011 Tentang Penetapan Dan Alih Fungsi Lahan Pertanian Pangan Berkelanjutan;

C. SuratE daran Menteri Negara Agraria/Kepala BPN No. 5335/M K/1994 intinya Penyusunan RTRW Dati II Melarang konversi Lahan S awah Irigasi Teknis untuk non Pertanian;

d. SuratE daran Menteri Negara Agraria/Kepala BPN 5417/MK/10/1994 intinyaefisiensi pemanfaatan lahan bagi pembangunan perumahan ;

e. Surat Edaran Menteri Dalam Negeri Nomor : 474/4263/SJ/1994 intinya agar mempertahankan sawah irigasi teknis untuk mendukung Swasembada pangan. 
f. Instruksi Gubernur KDH Tingkat I Jawa Tengah Nomor : 590/107/1985 Tanggal 25 Maret 1985 MengenaiPetunjuk Pelaksanaan Pencegahan Perubahan Tanah Pertanian ke Non Pertanian Yang Tidak Terkendali Di Propinsi J awa Tengah.

Berbagai regulasi memang telah diterbitkan oleh Pemerintah untuk melindungi dan mengendalikan lahan-lahan pertanian dari alih fungsi menjadi non pertanian, namun dengan perkembangan pembangunan dewasa ini yang semakin pesat dan nilai ekonomis tanah (pertanian) yang semakin tinggi, maka tidak dapat dibendung lagi trend para petani pedesaan yang mengalihkan fungsi tanah pertaniannya/merubah penggunaan tanah menjadi non pertanian (pekarangan) semakin banyak sekedar untuk investasi di masa depan.

MenurutAsrie Fajarani Hadipitoyo, dkk dalam kesimpulan penelitiannya tentang perubahan penggunaan tanah pertanian ke non pertanian di Kecamatan Selogiri, Kabupaten Wonogiri, menyatakan bahwa ada dampak positif dan negatifnya, yakni :

A. Dampak Positif

1.meningkatkan pendapatan pemohon;

2.membuka lapangan kerja;

3. meningkatkan pemasukan ke APBD;

4. meningkatkan nilai jual tanah.

B. Dampak Negatif

1.berkurangnya lahan basah;

2. pendapatan petani menurun;

3. pemborosan anggaran pembangunan;

4.kerusakan daya dukung lingkungan;

5. perubahan sosial.

(Asrie Fajarani Hadipitoyo, dkk, 2013 :9)

Di sisi lain, banyaknya permohonan izin perubahan penggunaan tanah yang diajukan oleh masyarakat Kabupaten Karanganyar ke Kantor Pertanahan Kabupaten Karanganyar, belum di imbangi dengan tersedianya pelayanan di bidang perizinan, khususnya izin perubahan penggunaan tanah (IPPT) oleh Pemerintah Daerah Kabupaten Karanganyar sesuai ketentuan yang berlaku. Dalam Undang-Undang No. 2 Tahun 2015 Tentang Penetapan Peraturan Pemerintah Pengganti Undang-Undang (Peperpu) No. 2 Tahun 2014 Tentang Perubahan Atas Undang-Undang No. 23 Tahun 2014 Tentang Pemerintahan Daerah Menjadi Undang-Undang dinyatakan bahwa urusan pertanahan (perizinan) merupakan urusan pemerintahan wajib yang tidak berkaitan dengan pelayanan dasar (Pasal 12 ayat 2 huruf d), sehingga pelayanan di bidang perizinan, termasuk izin perubahan penggunaan tanah seharusnya menjadi kewenangan Pemerintah Daerah (d.h.i. Pemerintah Daerah Kabupaten Karanganyar).

Adapun peraturan perundang-undangan yang mengatur perihal kewenangan Pemerintah Daerah Kabupaten/Kota di bidang perizinan adalah :

1. Undang-Undang No. 26 tahun 2007 Tentang Penataan Ruang.

Dalam pasal 7 ayat 1 dan ayat 2 Undang-

Undang tersebut menyatakan bahwa :

(1) Negara menyelenggarakan penataan ruang untuk sebesar-besarnya kemakmuran rakyat.

(2) Dalam melaksanakan tugas sebagaimana dimaksud pada ayat (1), negara memberikan kewenangan penyelenggaraan penataan ruang kepada Pemerintah dan Pemerintah Daerah.

2. Peraturan Pemerintah No. 15 Tahun 2010 Tentang Penyelenggaraan Penataan Ruang.

a. Dalam pasal 163 Ayat (2) yang berbunyi: "Izin pemanfaatan ruangsebagaimana dimaksud pada ayat (1) diberikan oleh pemerintah daerah Kabupaten/ Kota."

b. Dalam pasal 163 ayat (1) dijelaskan bahwa "Izin pemanfaatan ruang sebagaimana dimaksud dalam Pasal 162 ayat 1 dapat berupa :

a. izin prinsip;

b. izin lokasi:

c. izin penggunaan pemanfaatan tanah:

d. izin mendirikan bangunan dan izin lain berdasarkan ketentuan peraturan perundang-undangan

Namun, selama ini kewenangan tersebut masih dilaksanakan oleh Kantor Pertanahan Kabupaten Karanganyar atas dasar pelimpahan kewenangan dari Bupati Karanganyar.Dengan adanya pelimpahan kewenangan kepada Kantor Pertanahan Kabupaten Karanganyar sampai sekarang ini (2015), pelayanan tersebut dapat diselesaikan sesuai dengan Peraturan Kepala Badan Pertanahan Nasional No. 1 Tahun 2010 Tentang SOP (Standar Operasioanl Pelayanan) yakni rata-rata dalam waktu 1 (satu) bulan. 
Oleh karena itu, dengan tidak mengurangiketerbatasan kemampuan atas sarana dan prasarana penunjang pelayanan dari Pemerintah Daerah Kabupaten Karanganyar, agar pelayanankhususnya yang terkait dengan pemberian izin perubahan penggunaan tanah dimaksudtetap berjalan dan dapat dilayani dengan baik, maka Pemerintah Daerah Kabupaten Karanganyar sejak tahun 1998 mengambil inisiatif untuk melimpahkan kewenangan tersebut kepada Instansi lain, dalam hal ini kepada Kantor Pertanahan Kabupaten Karanganyar, hingga saat ini (2015).

Berdasarkan ketentuan-ketentuan tersebut di atas, dalam Artikel ini hendak dibahas alasan-alasan yang menjadi penyebab Pemerintah Daerah Kabupaten Karanganyar belum dapat melaksanakan kewenangan di bidang pemberian izin perubahan penggunaan tanah.

\section{B. Metode Penelitian}

Bentuk Penelitiannya penulis menggunakan bentuk Penelitian Evaluatif, yaitu bentuk penelitian yang akan menilai program-program yang dijalankan oleh Pemerintah Kabupaten Karanganyar. J enis penelitiannya menggunakan jenis penelitian normatif-empiris, yakni penelitian hukum terhadap identifikasi hukum (tidak tertulis) dan penelitian terhadap efektifitas hukum (Pedoman Pembibingan Tesis \& Pedoman Penulisan Usulan Penelitian \& Tesis, Program S tudi Magister (S2) IImu Hukum, FH UNS, 2013 : 9-10).

Adapun pendekatan penelitian, penulis mengambil pendekatan konseptual (conceptual approach) dengan mengkaji konsep-konsep hukum dan pandangan ahli yang relevan, serta pendekatan undang-undang (statute approach) dengan mengkaji peraturan perundang-undangan yang berkaitan dengan masalah pemberian izin perubahan penggunaan tanah.

Untuk tehnik pengumpulan data, penulis menggunakan metode wawancara yaitu suatu metode untuk pengumpulan data dengan mengajukan pertanyaan langsung kepada informan terkaitpermasalahan pelaksanaan kewenangan pemberian izin perubahan penggunaan tanah dari tanah pertanian ke non pertanian dan dengan menggunakan Studi Kepustakaan yaitu melakukan telaah pustaka atas data yang relevan dengan masalah-masalah yang terkait dengan obyek penelitian. Adapun sumber data diperoleh melalui data primer dandata sekunder.

\section{Hasil Penelitian Dan Pembahasan.}

\section{C.1. Pelaksanaan Kewenangan Dalam Pemberian Izin Perubahan Penggunaan tanah di Kabupaten Karanganyar.}

Berdasarkan hasil penelitian penulis di lapangan, di Kabupaten Karanganyar untuk pelaksanaan penyerahan kewenangan penerbitan Izin Perubahan Penggunaan Tanah (IPPT) kepada Kepala Kantor Pertanahan Kabupaten Karanganyartersebut, dilaksanakan sejak Tanggal 1 April 1999 berdasarkan Petunjuk Bupati Kepala Daerah Tingkat II Karanganyar pada Rapat Koordinasi Pengendalian Operasional Proyek (PDP) dan Rakor Bidang Pemerintahan Tanggal 4 Pebruari 1999. Namun, setelah berjalan kurang lebih 15 (lima belas) tahun kemudian, Kepala Kantor Pertanahan Kabupaten Karanganyardengan suratnya Nomor : 303/1433-400/III/2014 Tanggal 27 Maret 2014, Surat Nomor : 1233/400/XII/2014 tanggal 29 Desember 2014 , berkeinginan untuk menyerahkan kembali pelimpahan kewenangan tersebut kepada Bupati Karanganyar.Namun, Bupati Karanganyardengan Suratnya No. 590/5.900.1 tanggal 11 Agustus 2014 dan No. 590/1. 193.3 tanggal 5 Februari 2015 menegaskan kembali bahwauntuk pelayanan dan penerbitan izin perubahan penggunaan tanah sejak 1 J anuari 2015 agar tetap dilayani oleh Kantor Pertanahan Kabupaten Karanganyar sampai dengan instrument hukum dan sarana pendukung tersedia.

Adapun mekanime pemberian izin perubahan penggunaan tanah Pertanian Menjadi Non Pertanian, diawali dengan dengan permohonan Pertimbangan Teknis Pertanahan (PTP) terlebih dahulu sebagaimana diatur dalam Peraturan Kepala BPN RI No. 2 Tahun 2011 tentang Pedoman Pertimbangan Teknis Pertanahan Dalam Penerbitan Izin Lokasi, Penetapan Lokasi Dan Izin Perubahan Penggunaan Tanah.

Adapun tahapannya adalah sebagai berikut:

1) Tahap Penerbitan Pertimbangan Teknis Pertanahan (PTP).

Adapun syarat-syarat dan prosedur

(1).Pemohon akan menanyakan terlebih dahulu, apakah tanahnya dapat dialihfungsikan/dirubah penggunaannya menjadi pekarangan kepada Petugas 
Seksi Pengaturan Dan Penataan Pertanahan (Seksi P3)'

(2). Apabila Petugas setelah melihat Peta RTRW Kabupaten, tanah tersebut ternyata dapat dirubah penggunaannya, maka Petugas akan menyarankan kepada pemohon segera mengajukan permohonan dan mengisi formulir yang telah disediakan dengan dilampiri foto copy Kartu Tanda Penduduk (KTP)/akta pendirian, jika pemohon badan hukum, foto copy Sertifikat Hak Miliknya, foto copy SP PT PBB terakhir dan Sket lokasi letak tanah yang dimohon.

(3) .Setelah mengisi formulir-formulir dan melengkapi persyaratan tersebut di atas, kemudian menyerahkan ke Loket II(penerimaan berkas) kembali untuk diteliti kelengkapan berkasnya.

(4). S etelah berkas dinyatakan lengkap oleh petugas loket dan di entry, kemudian berkas tersebut diserahkan kepada Manajer Pelayanan;

(5). Kemudian Manajer pelayanan akan mengeluarkan Surat Perintah Setor (SPS) kepada pemohon agar membayar biaya pelayanan berupa $P$ enghasilan Negara Bukan Pajak (PNBP) kepada Negara, dengan Rumus Tptip : (L/500 x HSBKpa) + Rp. 350.000,- (PP No. 13/2010 Pasal 14).

(6). Kemudian berkas tersebut dikirim ke Seksi Pengaturan dan Penataan Pertanahan (S eksi P 3), untuk dibuatkan Surat Tugas Lapang.

(7). Hasil peninjauan lapang oleh seorang Petugas, kemudian dibuatkan Berita Acaranya sesuai kondisi tanah yang dimohon dan keadaan sekitarnya.

(8). Selanjunya dilakukan proses penelitian dan pengolahan data oleh Petugas yang ditunjuk oleh Kepala Kantor Pertanahan kepada (Tim PTP/6 Pejabat), yang susunan keanggotaan sebagai berikut:

i). Kepala Seksi Pengaturan Dan Penataan Pertanahan sebagai Ketua merangkap Anggota ;

ii). Kepala Sub Seksi Penatagunaan Tanah Dan Kawasan Tertentu sebagai Sekretaris merangkap Anggota ;

iii) .Kepala Sub Seksi Landreform Dan Konsolidasi Tanah sebagai Anggota; iv). Kepala Sub Seksi Pendaftaran Hak Tanah sebagai Anggota; Kepala Sub Seksi Pengendalian Pertanahan sebagai Anggota; Kepala Sub Seksi Tematik dan Potensi Tanah sebagai nggota.

Yang mempunyai bertugas melakukan analisa penatagunaan tanah, Analisa atas obyek/tanahnya, analisa lingkungan sekitarnya, berpedoman pada ketentuan RTRW Kabupate, dan analisa ketersediaan tanah.

(9). Setelah itu, Tim Pertimbangan Teknis Pertanahan mengadakan rapat untuk memutuskan apakah permohonan tersebut dapat dipertimbangan atau tidak, yang dituangkan dalam Berita Acara Rapat Tim Pertimbangan Teknis Pertanahan, dengan mempertimbangkan:

i. kesesuaian rencana kegiatan yang dimohon dengan RTRW ;

ii. kemampuan pemohon ditinjau dari proposal pemohon;

iii. kelayakan luas yang dimohon berdasarkan kemampuan pemohon, tahapan kegiatan dan ketentuan batas luas maksimum tanah yang dimohon;

iv .status tanah dan gambaran umum penguasaan tanah di lokasi yang dimohon, terutama terkait dengan aset pemerintah dan pemerintah daerah;

v. keberadaan izin lokasi dan perizinan lainnya;

vi. keberadaan sengketa, konflik dan perkara pertanahan di lokasi yang dimohon ;

vii.pencegahan alih fungsi sawah beririgasi;

viii. kawasan-kawasan yang dilindungi seperti hutan lindung dan ketersediaan tanah secara fisik dan yuridis.

(10). Apabila hasil pembahasan Tim PTP mempertimbangkan /mengabulkan permohonan, maka selanjutnya Tim PTP akan membuat Konsep Risalah Pertimbangan Teknis Pertanahan dalam Penerbitan Izin Perubahan Penggunaan Tanah, berikut $P$ eta-peta pendukung.

(11).Kemudian konsep Risalah beserta berkas-berkas kelengkapan permohonan 
tersebut diteruskan kepada Kepala Kantor Pertanahan untuk mendapatkan persetujuan;

(12). Apabila dapat dipertimbangkan, maka Kepala Kantor Pertahahan akan menandatangani Risalah Pertimbangan Teknis Pertanahan Dalam Penerbitan Izin Perubahan Penggunaan Tanah (IPPT).

(13).Penyerahan Pertimbangan Teknis Pertanahan (PTP) tersebut, yang dilakukan dengan tanda terima kepada pemohon.

2). Tahap Pemohonan Izin Perubahan Penggunaan Tanah (IPPT).

Syarat-syaratnya

(1). Pemohon mengisi formulir permohonan izin perubahan penggunaan tanah dan formulir surat pernyataan yang telah disediakan (rangkap 3), dengan dilampiri Asli Risalah Pertimbangan Teknis Pertanahan (PTP) an. Pemohon, foto copy sertifikat Hak Milik, Sket lokasi, SPPT PBB terkhir ;

(2). Prosedur/tata caranya

i. pemohon segera mengajukan permohonan Izin Perubahan Penggunaan Tanah tersebut ke Loket, dengan melampirkan berkasberkas kelengkapan permohonan sebagaimana tersebut di atas ;

ii. Setelah berkas lengkap, selanjutnya dilakukan pengolahan data oleh Staf/petugas administrasi mengenai kelengkapan permohonan dan pengecekan kembali kesesuaian lokasi tanah yang dimohon dengan Peta Rencana Tata Ruang Wilayah Kabupaten Karanganyar (RTRW) Kabupaten;

iii. Kemudian Kepala Seksi PPP melaporkan kepada Kepala Kantor Pertanahan perihal berkas permohonan tersebut dan untuk membuat konsep Undangan Rapat koordinasi yang ditujukan kepada segenap Anggota Panitia Perubahan Penggunaan Tanah Kabupaten (Tim 9);

iv. Apabila berdasarkan Rapat Koordinasi Panitia tersebut, permohonan tersebut telah memenuhi persyaratan administrasi dan persyaratan teknis, serta setelah dilakukan peninjuan lokasi sesuai dengan kondisi fisik tanah yang dimohon, maka selanjutnya Kepala Kantor Pertanahan Kabupaten menandatangani Konsep Surat Keputusan Kepala Kantor Pertanahan Kabupaten tentang Izin Perubahan Penggunaan Tanah tersebut kepada pemohon;.

v. Selanjutnya Surat Keputusan Kepala Kantor Pertanahan Kabupaten, diserahkan kepada Pemohon ;

vi. Setelah Surat Keputusan diterima Pemohon, kemudian kepada pemohon diperintahkan mencatatkan ke Bagian Pendaftaran Hak, Seksi Hak tanah dan Pendaftaran Tanah (HT dan PT).

3). Tahap pendaftaran/pencatatan perubahan penggunaan tanah dalam sertifikat hak atas tanah

Persyaratan dan prosedurnya adalah :

i. Pemohon mengambil formulir pendaftaran di Bagian informasi (CRS), di isi dan dilampiri Asli Sertipikat HakA tas Tanah, foto copy Kartu Tanda Penduduk dan asli SK Izin Perubahan Penggunaan Tanah;

ii. Apabila semua persyaratan sudah komplit, kemudian di entry dan keluar Surat Perintah Setor (SPS).

iii. Selanjutnya dilakukan pembayaran atasSPS (PNBP/Rp. 50.000,-) tersebut ke Loket Pembayaran/ Loket 2;

iv. Kemudian berkas tersebut, oleh petugas dibawa ke bagian Buku Tanahnya untuk dicocokan dan bila cocok nomer hak dan pemohonnya, kemudian berkas beserta buku tanah terssebut, diserahkan ke bagian Pendaftaran Hak dan Informasi;

v. Selanjunya oleh petugas dilakukan pencatatan pada buku tanah dan sertifikatnya adanya perubahan penggunaan tanah tersebut, kemudan dimintakan Paraf Kasubsi dan paraf Kepala Seksi sebelum ditandatangani oleh Kepala Kantor.

Dibawah ini Penulis sajikan gambaran 
Data Perubahan Penggunaan Tanah Pertanian ke Non Pertanian di Kantor Pertanahan Kabupaten Karanganyar dalam 3 (tiga) terakhir antara Tahun 2013 sd 2015 sebagai berikut :

a. Tahun 2013, permohonan perubahan penggunaan tanah menjadi non pertanian (sawah dan tegalan) berjumlah 590 bidang, seluas $56,2496 \mathrm{Ha}$;

b. Tahun 2014, permohonan perubahan penggunaan tanah menjadi non pertanian (sawah dan tegalan) berjumlah 616 bidang, seluas $54,0045 \mathrm{Ha}$;

c. Tahun 2015, permohonan perubahan penggunaan tanah menjadi non pertanian (sawah dan tegalan) berjumlah 441 bidang, seluas 55,3809 $\mathrm{Ha}$;

Berdasarkan data yang ada tersebut di atas, menunjukkan bahwa jumlah tanah pertanian yang dilakukan perubahan penggunaan tanah/alih fungsi menjadi non pertanian atas permohonan masyarakat dalam waktu 3 (tiga) tahun terakhir sejumlah 1.647 bidang, atau seluas 165,6350 hektar, sehingga jika di rata-rata dalam 1 (satu) tahun, maka jumlah terjadinya alih fungsi/ perubahan penggunaan tanah adalah 549 bidang per tahun atau 55,2116 Hektar/tahun.

Dengan demikian, sisa luas tanah pertanian (sawah dan Tegalan) seluruhnya di Wilayah Kabupaten Karanganyar adalah luas seluruhnya seluas $\pm 35.404 \mathrm{Ha}$, dikurangi dengan luas hasil perubahan penggunaan tanah ke Non P ertanian selama 3 (tiga) tahun terakhir seluas 165,6350 Ha sama dengan 35.2380 hektar. Dengan demikian masih ada lahan cadangan pertanian seluas \pm 11.497 $\mathrm{Ha}$, di luar lahan LP2B (Lahan Pertanian Pangan Berkelanjutan).

C.2. Alasan-alasan Yang Menjadi Penyebab Pemerintah Daerah Kabupaten Karanganyar Belum Dapat Melaksanakan Kewenangan Di Bidang Pemberian/ Penerbitan Izin Perubahan Penggunaan Tanah (IPPT).

Pemerintah Daerah Kabupaten Karanganyar sampai Akhir Tahun 2015 belum dapat melayani permohonan pemberian izin perubahan penggunaan tanah yang diajukan oleh masyarakat atau badan hukum untuk keperluan rumah tinggal atau sarana penunjang perusahaan.
Adapun alasan-alasan yang menjadi penyebab Pemerintah Kabupaten Karanganyar belum dapat melaksanakan pelayanan di bidang izin perubahan penggunaan tanah, secara umum telah dijelaskan oleh Bupati Karanganayar dalam Surat Bupati Karanganyar Nomor : 590/5.900.1 Tanggal 11 Agustus 2014 dan Surat Bupati Karanganyar Nomor : 590/1.193.3 Tanggal 05 Februari 2015 antara lain sebagai berikut :

\section{a. Belum adanya Instrumen hukum}

Instrumen hukum dimaksud adalah Peraturan Bupati Karanganyaryang baru yang mengatur tentang Izin Perubahan Penggunaan Tanah (IPPT) dan Peraturan Daerah yang mengatur tentang Struktur Organisasi dan Tata Kerja (SOT) Lembaga Teknis Daerah berupa Badan Penanaman Modal dan Pelayanan Terpadu S atu P intu (BPMPTSP).

b. Belum adanya sarana/prasana pendukung teknis

Yang berupapeta Rencana Tata Ruang Wilayah Kabupaten yang sudah dilakukan pengeplotan atas izin perubahan penggunaan tanah yang telah diterbitkan, peta-peta Penggunaan Tanah/P eta RDTR dengan skala 1 : 5000 dan Peta lokasi/letak tanah yang dimohonkan Izin perubahan penggunaan tanah.

\section{c. Sumber Daya Manusia (SDM)}

Pemerintah Daerah Kabupaten Karanganyar belum menyiapkan personil atau Staf yang dilatih/dibekali pengetahuaan, ketrampilan administrasi maupun teknis guna menerima penyerahan kewenangan dari Kantor Pertanahan Kabupaten Karanganyar terkait pelayanan izin perubahan penggunaan tanah.

Dengan demikian, menurut hemat penulis alasan-alasan yang menjadi penyebab Pemerintah Daerah Kabupaten Karanganyar belum mampu melaksanakan sendiri kewenangan di bidang perizinan, khususnya izin prubahan penggunaan tanah, penulis sependapat dengan Pendapat/Teori Soerjono Soekanto mengenai faktor-faktor yang mempengaruhi bekerjanya hukum dalam masyarakat (Soerjono Soekanto, 1982 : 9) yaitu : 
a. Faktor Peraturan Perundang-undangan Perangkat/Instrumen hukum atau peraturanperundang-undangan tersebut adalah belum dipunyai adanyaPeraturan Bupati Karanganyar yang mengatur mengenai izin perubahan penggunaan tanah dan Peraturan Daerah yang mengatur tentang Struktur Organisasi dan Tata Kerja (SOT) Lembaga Teknis Daerah berupa Badan Penanaman Modal dan P elayanan Terpadu Satu P intu (BPMPTSP).

b. Aparat Pelaksana

Pemerintah Daerah Kabupaten Karanganyar belum menyiapkan personil atau Staf yang dilatih/dibekali pengetahuaan, ketrampilan administrasi maupun teknis yang cukup guna menerima pelimpahan kewenangan dari Kantor Pertanahan Kabupaten Karanganyar terkait pelayanan izin perubahan penggunaan tanah.

c. Sarana dan prasarana

Sarana dan prasarana teknistersebut adalah berupapeta Rencana Tata Ruang Wilayah Kabupaten yang sudah dilakukan pengeplotan atas izin perubahan penggunaan tanah yang telah diterbitkan, peta-peta Penggunaan Tanah/P eta RDTR dengan skala 1 : 5000 dan Peta lokasi/letak tanah yang dimohonkan Izin perubahan penggunaan tanah.

d. Dana

Faktor dana/anggaran yang besar menjadi salah satu hambatan atau penyebab belum tersedianya 2 (dua) instrument/perangkat hukum (P eraturan Daerah dan Peraturan Bupati), tersedianya sarana dan prasarana teknis serta sumber daya manusia.

e. Masyarakat

Masyarakat Kabupaten Karanganyar mempunyai tingkat pengetahuan dan kesadaran hukum yang tinggi terhadap setiap peraturan perundang-undangan yang telah diberlakukan, khususnya yang terkait nilai ekonomis tanah pertanian yang akan dirubah penggunaan menjadi non pertanian (pekarangan) untuk nrumah ntinggal atau sekedar investasi.

\section{Kesimpulan}

Berdasarkan pada hasil penelitian dan pembahasan yang dilakukan penulis terhadap pelaksanaankewenangan dalam pemberian izin perubahan penggunaan tanah pertanian menjadi non pertanian, maka dapat disimpulkan hal-hal sebagai berikut :

1. Alasan-alasan yang menjadi penyebab Pemerintah Kabupaten Karanganyar belum dapat melaksanakan kewenangan di bidang pelayanan pemberian/penerbitan Izin Perubahan Penggunaan Tanah Pertanian menjadi Non Pertanian, dikarenakan :

a. Belum adanya perangkat/Instrumen hukum sebagai dasar pelayanan izin perubahan penggunaan tanah, yakniP eraturan Bupati Karanganyar yang mengatur mengenai izin perubahan penggunaan tanah dan Peraturan Daerah yang mengatur tentang Struktur Organisasi dan Tata Kerja (SOT) Lembaga Teknis Daerah berupa Badan Penanaman Modal dan Pelayanan Terpadu Satu P intu (BPMPTSP).

b.. Belum adanya sarana dan prasana teknis yang mendukung dalam rangka pelaksanaan kewenangan tersebut, yang meliputi peta penggunaan tanah Kabupaten Karanganyar berskala 1 : 5000 untuk melakukan pengeplotan atas izin perubahan penggunaan tanah yang telah diterbitkan, peta lokasi/letak tanah yang dimohonkan Izin perubahan penggunaan tanah dengan Skala 1 : 5000, dan;:

c. Belum menyiapkan sumber daya manusia (pejabat/personil) dalamdalam Struktur Organisasi dan Uraian Tugas (SOT) yang baru ke dalam Badan Penanaman Modal dan Pelayanan Terpadu Satu Atap (BKM-PTSP).

2. Penulis sependapat dengan Teori bekerjanya hukum yang dikemukakan oleh Soerjono Soekanto, yang menyatakan bahwa alasanalasan yang menjadi penyebab Pemerintah Kabupaten Karanganyar belum dapat melaksanakan kewenangannya sendiri di bidang izin perubahan penggunaan tanah, adalah sesuai dengan faktor-faktor yang mempengaruhi bekerjanya hukum, yakni peraturan perundang-undangan ysng belum tersedia, belum tersedianya sarana dan 
prasarana teknis, faktor belum tersedianya sumber daya manusianya, dan dana yang cukup besar.

\section{E. Saran}

1. Agar tidak terjadi hambatan dan tetap terselenggaranya pelayanan yang baik terhadap setiap permohonan izin perubahan penggunaan tanah dari masyarakat Kabupaten Karanganyar serta sambil menunggu tersedianya instrument-instrumen hukum dan sarana/prasarana penunjang yang sedang dipersiapkan oleh Pemerintah Daerah Kabupaten Karanganyar, maka disarankan untuk sementara waktu terhadap urusan perizinan, khususnya izin perubahan perubahan penggunaan tanah dilimpahkan kepada Kantor Pertanahan Kabupaten Karanganyar.

2. Berdasarkan hal tersebut, hendaknya Pemerintah Kabupaten Karanganyar melakukan koordinasi dengan Satuan Kerja Perangkat Daerah (SKPD) terkait di bawahnya serta kerja sama yang baik dengan Instansi Vertikal di Wilayahnya, yakni Organ Kementerian Agraria dan Tata Ruang/ BPN Cq. Kantor Pertanahan Kabupaten Karanganyar dalam rangka menunjang kelancaran pelayanan perizinan dimaksud.

\section{Daftar Pustaka}

\section{A. Buku}

Maria Sri Wulan Sumardjono. 2001. "Kebijakan Pertanahan Antara R egulasi dan Implementasi, "Artikel. J akarta. Kompas. dikutip dari Samun Ismaya, "Pengantar Hukum Agraria," Cetakan Pertama. Graha Ilmu Yogyakarta.

Soerjono Soekanto dan Musthofa Abdullah. 1982. "S osiologi Hukum Dalam Pengantar, "Cetakan Ke-2. J akarta. CV. Radjawali.

\section{B. urnal dan Makalah}

Asrie Fajarani Hadipitoyo, dkk. 2013. "Perubahan Penggunaan Tanah Pertanian Menjadi Non Pertanian di Kabupaten Wonogiri (Studi di Kecamatan Selogiri)," Diponegoro Law Review. Volume 1 Nomor 2.

Govindaprasad.P.K and K. Manikandan. 2014. "Agricultural Land Conversion And food Security : A Thematic Analisys," Artikel, pada International Research J ournal Of rural Development, ISSN : 2319-331X. Vol 3. No.1. Tamil Nadu. India.

Lutfi Nasoetion dan Ernan Rustiadi. 1990. "Masalah Konservasi Lahan Sawah ke Penggunaan Non Sawah Fokus J awa Bali," Makalah PAU Studi Sosial UG M...... BUKU

Mc Neil. 1998. "Faktor-faktor Yang Mendorong Perubahan Penggunaan Lahan, "dikutip dari Linda Dwi Rohmadiani, "Dampak Konversi Lahan P ertanian Terhadap Kondisi Sosial E konomi P etani,"J urnal Tehnik Waktu, Volume 09 Nomor 02 - J uli 2011- ISS N :1412-1867. Surabaya.

Syarif Imam Hidayat. 2008." Analisis Konversi Lahan Sawah di Prop. J atim," Artikel J - SEP, Vol 2 no. 3 Nopember 2008.

\section{Peraturan Perundang-undangan}

Undang-Undang Pokok Agraria (UU No. 5 Tahun 1960) Tentang Ketentuan Pokok Dasar-dasar Agraria. Undang-Undang No. 26 Tahun 2007 Tentang Penataan Ruang

Peraturan Pemerintah No.. 15 Tahun 2010 Tentang Penyelenggaraan Penataan Ruang. 
Instruksi Gubernur KDH Tingkat I J awa Tengah Nomor : 590/107/1985 Tanggal 25 Maret 1985 Tentang Pencegahan Perubahan Tanah Pertanian Ke Non Pertanian Yang Tidak terkendali.

Peraturan Daerah Kabupaten Karanganyar No. 1 tahun 2013 Tentang Rencana Tata Ruang Wilayah Kabupaten Karannanyar, Tahun 2013 - 2033.

Keputusan Gubernur KDH Tk.I J awa Tengah No. 06 Tanggal 20 Juli 1998 tentang Pengendalian Penggunaan Tanah Pertanian Sawah untuk Kegiatan Non Pertanian.

Undang-Undang No. 2 Tahun 2015 Tentang Penetapan Peraturan Pemerintah Pengganti UndangUndang (Peperpu) No. 2 Tahun 2014 Tentang Perubahan Atas Undang-Undang No. 23 Tahun 2014 Tentang Pemerintahan.

\section{Surat Kabar dan Majalah}

Lutfi Nasoeion. 2003. Harian Kompas, Edisi 13 Juni 2003.

\section{Data sekunder}

Data Biro Pusat Statistik Tahun 2001.

Data Hasil Audit Kementerian Pertanian Repunlik Indonesia pada Tahun 2010 dan Tahun 2012.

Hasil Temuan dan Analisis Terhadap Permasalahan Pengendalian Alihfungsi lahan Sawah Oleh Kajian Tim Peneliti pada PusatA nalisis Sosial Ekonomi dan Kebijakan Pertanian bersama Staf Direktorat Pangan dan Pertanian, Kantor Meneg PPN/BAPPENAS. 